\section{AL-AZHAR}

Assiut Dental Journal
The Official Publication of The

Faculty of Dental medicine.

Al-Azhar Assiut Uniuersity.

AADJ, Vol. 3, No. 2, October (2020) - PP. 105:112

ISSn 2682-2822

\title{
Immediate Implant Placement Combined With Sticky Bone and Enriched Fibrin Membrane For Teeth Exhibiting Periapical Pathosis
}

\author{
Mohamed, E . Eid"1 ${ }^{* 1}$ Mohamed A. Mohamed ${ }^{2}$, Bahaa Al-Din A Tawfik ${ }^{3}$
}

Codex : 13/2020/10

Aadj@azhar.edu.eg

\section{KEYWORDS}

Keywords: Immediate implant, Sticky bone, Enriched fibrin membrane, Periapical pathosis, $C B C T$

1. B.D.S,2010 G faculty of dentistery oct6 university

2. Professor, department of Oral and Maxillofacial surgery, faculty of Dental medicine, boys,cairo Al-azhar University

3. Ass. Professor, department of Oral and Maxillofacial surgery, faculty of Dental medicine, boys,cairo Al-azhar University

* Corresponding Author e-mail: mohamedeid $97 @$ azhar.edu.eg

\begin{abstract}
Aim: This study was designed to evaluate immediate implant placement combined with sticky bone and enriched fibrin membrane for teeth exhibiting periapical pathosis clinically, radiographically and resonance frequency analysis. Subjects and methods: Thirteen immediate implant combined with sticky bone and CGF membrane were inserted in 13 patients suffering from teeth with periapical pathosis indicated for extraction. Preoperative cone beam CT (CBCT were taken for every patient to determine alveolar bone height, width and bone defects The change in the implant stability and bone density readings were measured using ostel device and (CBCT) immediatly, and after 6 months of healing. Results: the mean values of ISQ was 48, 02 1ry stability . After 6 months, the mean value was increased to 72. Increasing of ISQ was observed with the time with significant statistical difference in the value of ISQ in whole time of evaluation and There was statistically significant increase of bone density readings after 6 months. Conclusion: The Immediate implant placement combined with sticky bone and enriched fibrin membrane for teeth exhibiting periapical pathosis is a successful technique
\end{abstract}

\section{INTRODUCTION}

Immediate implant placement has both social and economic advantages. The overall treatment time is reduced, a second surgical intervention is avoided, and there is a decrease in rehabilitation treatment time $^{(1)}$ because it minimizes the number of surgical procedures by combining extraction, implant placement, and bone grafting (if needed) into one appointment. ${ }^{(2)}$ Less evident advantages comprise improved implant survival rates, enhanced hard and soft tissue maintenance, and there is the ability to place the fixture in an ideal axial position. ${ }^{(3)}$ Some studies on immediate implants suggested that this procedure should be avoided in the presence of periapical or periodontal pathosis, ${ }^{(3-5)}$ and clinical reports have suggested that history of periodontal or endodontic infections is a predictive marker for implant infection and failure. ${ }^{(6,7)}$ 
Additionally, cases of retrograde peri-implantitis have been thought to result from placement into such sites. ${ }^{(8,9)}$ The presence of chronic periodontal disease has also been correlated with an increased risk of implant failure ${ }^{(10-12)}$

This clinical experience has led most clinicians to avoid the immediate placement of endosseous dental implants at infected sites and to consider infection a contraindication for immediate implantation ${ }^{(13.14) \text {, }}$ More recent literature, however, has investigated placement into sites exhibiting periapical pathosis with successful outcomes. ${ }^{(15-1}$

A new concept of fabricating growth factorsenriched bone graft matrix (also known as sticky bone using autologous fibrin glue has been demonstrated since $2010^{(18)}$. Sticky bone provides stabilization of bone graft in the defect, therefore, accelerates tissue healing as well as minimizes bone loss during healing period., it is moldable, well adapted over various shape of bony defect, resulting in preventing micro and macro movement of grafted bone. So the volume of augmentation is maintained during healing period, and the need of bone block and titanium mesh is minimized ${ }^{(19,20)}$, also CGF (concentrated growth factors) membrane is used as barrier membrane alternative to collagen membrane to achieve GBR (guided bone regeneration) and to increase soft tissue healing ${ }^{(21)}$

\section{PATIENT AND METHODS}

Thirteen patients were carefully selected from outpatient clinic at the department of Oral and Maxillofacial Surgery, faculty of dental medicine, Cairo (boys), Al-Azhar University, each patient complaining of a tooth with periapical pathosis needed to be extracted and replaced with immediate implant placed in fresh extracted socket, so in this study we have thirteen patient having thirteen implants.

\section{Clinical evaluation:}

Intraoral and extra oral examinations were carried; hard and soft tissue structures were evaluated .eg bone contour, and gingival biotype TMJ disorders as subluxation, dislocation.

\section{Radiographic evaluation:}

Periapical x-ray and Panoramic x-ray were performed before extraction to detect bone level, and presence of any pathological lesions implant site. Also Cone Beam Computed tomography (CBCT) for detection of width and length of the implants. And vital structures

\section{Surgical procedures:}

All patients were subjected to prophylactic preoperative antibiotic. One hour before surgery, After testing of the anaesthesia the patient was ready for exposure of the field. to allow convenient retraction of soft tissue for unimpeded access for implant.

After the tooth has been extracted. the socket was cleaned and irrigated with normal saline to flush any debris from the socket and allow good visibility of the site for inspection of any remnant. Then, the socket was irrigated with chlorhexidine gluconate $0.12 \%$ solution to prevent and treat infection.

The socket has been curetted by bone curette, as it is mandatory procedures for any immediate implant case to remove the remnant of periodontal ligament and any granulation or fibrous tissue inside the socket that may enhance the fibro integration and subsequently retard the ossteointegration

Drilling has been extended $2-3 \mathrm{~mm}$ apically beyond the apex of the root or the base of the socket to gain primary stability for the implant from the apical bone.

\section{Preparation of sticky bone and CGF membrane}

1. 20-60 CC of patient's venous blood was taken from patient's vein. the blood was divided to one to two non-coated vacutainers to obtain autologous fibrin glue (AFG), which will make sticky 
bone and two to seven glass coated test tubes without anticoagulants to obtain CGF layer

2. The blood in the test tubes was centrifuged at 2400-2700 rpm for 12 minutes, The centrifugation time for AFG varies from 2-12 minutes. To get higher growth factors, the centrifuge will be stopped after 2 minute-centrifugation and take AFG tube out of the centrifuge first.

3. The non-coated tube showed 2 different layers. The upper layer is autologous fibrin glue (AFG) layer and the buttom layer is red blood cell layer which will be discarded. And centrifugation will be continued to prepare CGF.

4. After centrifugation, silica coated showed three different layers. The most upper layer is platelet poor plasma, and the middle layer is fibrin buffy coat layer represented by a very large and dense polymerized fibrin block containing the concentrated growth factors. The bottom layer is red blood cell layer. Non-coated yellow cap tube shows two different layers. The upper layer is AFG layer and the bottom layer is accumulation of red blood cell is which will be is discarded the middle layer will be taken in test tube and placed in the metal storage box and compress with metal cover to convert to CGF membrane .

5. The upper AFG will be obtained with syringe and mixed with particulate bone powder and allows for 5-10 minutes for polymerization in order to produce sticky bone

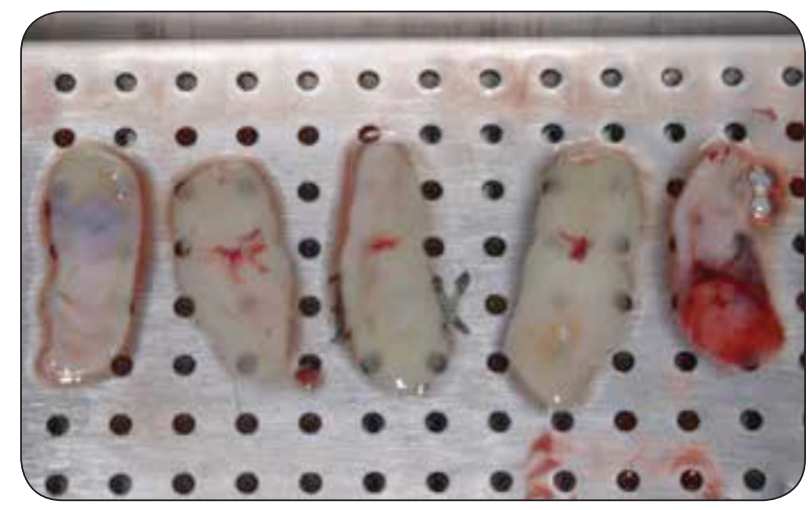

CGF membrane after compressing with metal cover.

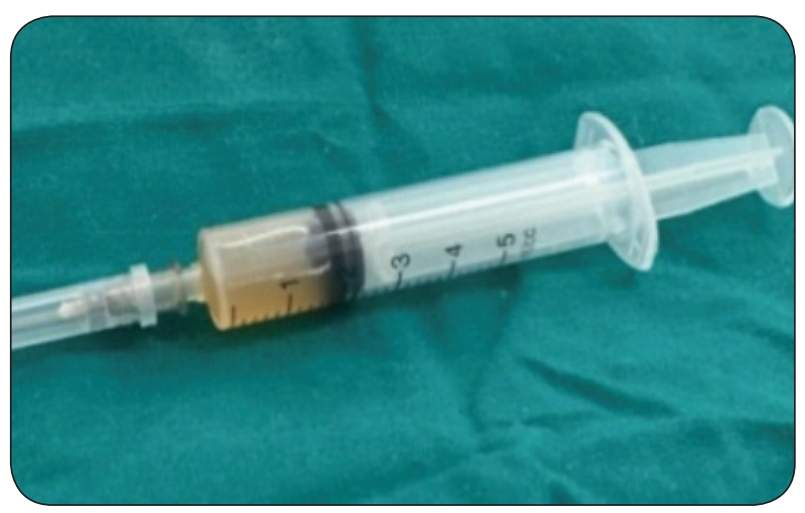

AFG used for sticky bone preparatio

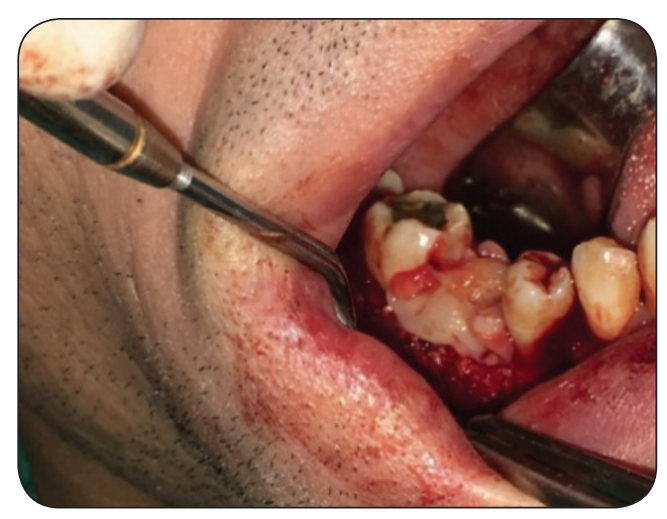

CGF membrane cover the sticky bone graft.

Flap was repositioned in its place and soft tissue had been closed over the implant using (vicryl) 3-0 suture.

Patients were instructed to take a postoperative medications

\section{Patient Follow up:}

The first visit was 3 days after the operation to check the site of surgery and assure that patients followed the given instructions.

The second visit was at $7^{\text {th }}$ day after surgery to remove the stitch. Postoperative photographs. 


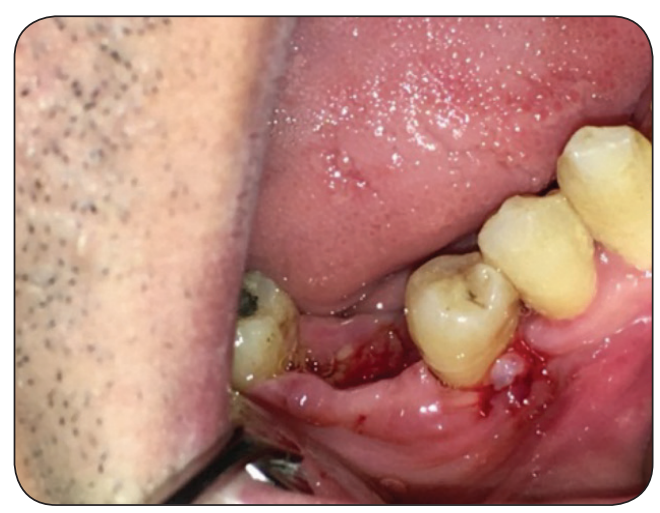

Photograph showing soft tissue healing after 7 days.

\section{RESULTS}

Thirteen implants were placed in fresh extraction sockets of thirteen patients, 6 males and 7 females. The patient's age ranged from 22 to 40 years with mean of 31.08 year. The implants inserted in all patients in same manner, 6 implants were placed in male patients and 7 implants were inserted in female patients. However, there was no statistically significant effects of sex, age on the obtained results

\section{Clinical evaluation}

All patients had been examined periodically during the follow-up period up to 6 months. Healing was uneventful in all cases with no post-operative complications.

Pain, swelling or infection; Pain was evaluated postoperatively using the visual analogue scale (VAS) (174) on the first and seventh days. Patients were asked about the pain severity after surgery, all patients experienced slight to mild pain at the surgical site. Eight had slight pain and showed mild edema which subsided totally by the 2 nd postoperative day. Five others had mild pain and mild edema which also disappeared completely by the 2nd post-operative day.

Eleven patients continued the follow up period without signs of infection while tow patients had mild postoperative infection and swelling it has been noted that the patients was not care about the treatment subsequently his oral hygiene. The infection disappeared completely after administration of antibiotics, mouth wash and NSADS,

\section{Implant stability}

The average values of stability (ISQ) measured with Osstell after attachment of transducer (Smart beg) to implant fixture. Immediately after implant insertion (0-day), the mean values of ISQ was 48,02 in the 1st stage. At 6 months, the mean was increased to 72 and. Increasing of ISQ was observed with the time in with significant statistical difference in the value of ISQ in whole time of evaluation particularly

\section{CBCT readings}

The bone density readings around implants by (HU) was obtained from the (CBCT) preoperative and after 6 months

\begin{tabular}{|c|c|c|c|c|c|}
\hline \multicolumn{2}{|l|}{ Immediate } & \multicolumn{2}{|c|}{ After 6Months } & \multirow{2}{*}{ “t” } & \multirow{2}{*}{ Probability } \\
\cline { 1 - 3 } Mean & St Dev & Mean & St Dev & & \\
\hline 649.92 & 118.20 & 787.42 & 75.28 & 4.598 & $0.0003 *$ \\
\hline
\end{tabular}

CBCT reading immediately and 6 months postoperatively

\section{DISCUSSION}

Some clinical studies have suggested that a history of periodontal disease and periapical infection could be used as a predictive marker of peri-implant disease, as well as implant failure ${ }^{(22)}$ and discourage the placement of implants in the presence of periapical and periodontal pathology. The reason is that there might be a potential contamination of the implant during the initial phase of wound and bone healing due to the remnant of infection, which affects the osseointegration process ${ }^{(23,24)}$

In the current study, socket curettage after tooth extraction was done to remove the pathological tissue and the remnant of periodontal ligaments the aim of debridement is the complete removal of the 
underlying infected tissue. The socket was irrigated with chlorhexidine gluconate $0.12 \%$ solution. The presence of infection is known to cause failure or delay in the healing process and even the deterioration of injured tissues (24) Therefore, the prevention of bacterial contamination and a tight control of bacterial plaque are essential to achieve successful results. ${ }^{(25)}$

In the present study all patients experienced slight to mild pain at the surgical site. Eight had slight pain and showed mild edema which subsided totally by the 2nd post-operative day. Five others had mild pain which also disappeared completely by the 2 nd post-operative due to administration of antibiotics, mouth wash, NSADS and using CGF membrane which increase soft tissue healing therefor decreasing pain duration and intensity.

Sticky bone is biologically solidified bone graft which is entrapped in fibrin network. Sticky bone graft doesn't scatter even upon being shaken with cotton plier because particulate bone powders are strongly interconnected each other by fibrin network. Sticky bone has numerous advantages: it is moldable, so well adapted over various shape of bony defect, Micro and macro movement of grafted bone is prevented. So the volume of augmentation is maintained during healing period, therefore the need of block bone and titanium mesh is minimized, Fibrin network entraps platelets and leukocytes to release growth factors, so bone regeneration and soft tissue is accelerated, No biochemical additives are needed to make sticky bone unlike PRP or PRGF; and Fibrin interconnection minimizes soft tissue ingrowth into the sticky bone graft in agreement with (Sohn DS) ${ }^{(21)}$.

In the present study, the combination of sticky bone, CGF membrane and immediate post extraction implant placement led to good clinical outcomes. The high success rate, preservation of hard and soft tissues, and patient satisfaction with the esthetic and functional outcomes show that this clinical procedure can be considered a safe, effective, and predictable treatment option for the immediate rehabilitation of fresh post extractioninfected sockets.

Compared to PRP and PRGF, PRF and CGF is simple to make and doesn't require any synthetic or biomaterials, such as bovine thrombin and calcium chloride, to make gel condition. So it is free from the risk of cross-contamination. ${ }^{(28)}$ Fibrin rich gel is known to release slowly growth factors such as transforming growth factor, platelet-derived growth factor and vascular endothelial growth factor and accelerates new bone formation in agreement with. (Choukroun and You.Tm) ${ }^{(29-30)}$.

In the present study Unlike PRF using constant centrifugation, CGF utilize altered centrifugation speed from 2,400-2,700 rpm to isolate much larger, denser and richer in growth factors enriched fibrin matrix

In the present study, the mean values for primary stability of the implant were 48,02 immediately and the secondary stability values were 72,92 at 6 months post implant insertion respectively. The stability of the implant fixture has been achieved without any mobility or signs of implantitis.

\section{CONCLUSIONS}

\section{This study concluded that:}

1- Immediate implant placement could be indicated in chronic infected lesions following a protocol that includes antibiotic therapy, debridement, and antisepsis of the compromised tissue, high primary implant stability, good soft tissue closure and good oral hygiene maintenance.

2- Clinically using the "sticky bone" and CGF membrane is very important, because the "sticky bone" facilitates the use and application of the graft, provides stability to the graft due to its fibrin network and therefore, accelerates tissue healing and minimizes bone loss during healing period. 
3- Sticky bone is moldable, prevents movement of grafted bone entraps platelets and leukocytes in its fibrin network, prevents ingrowth of soft tissues in graft, simple and natural economic preparation without any chemical additives.

\section{REFERENCES}

1. Casap N, Zeltser C, Wexler A, Tarazi E, Zeltser R. Immediate placement of dental implants into debrided infected dentoalveolar sockets. J Oral Maxillofacial Surg 2007; 65:384-392.

2. Lindeboom JA, Tjiook Y, Kroon FH. Immediate placement of implants in periapical infected sites: a prospective randomized study in 50 patients. Oral Surg Oral Med Oral Pathol Oral Radiol Endod 2006; 101:705-710.

3. Marconcini S, Barone A, Gelpi F, Briguglio F, Covani U. Immediate implant placement in infected sites: a case series. J Periodontol 2013; 84:196-202

4. Fugazzotto P. A retrospective analysis of immediately placed implants in 418 sites exhibiting periapical pathology: results and clinical considerations. Int J Oral Maxillofac Implants 2012; 27:194-202.

5. Fugazzotto PA. A retrospective analysis of implants immediately placed in sites with and without periapical pathology in sixty-four patients. J Periodontol 2012; 83:182-186.

6. Polizzi G, Grunder U, Goené R, Immediate and delayed implant placement into extraction sockets: a 5-year report. Clin Implant Dent Relat Res 2000; 2:93-99.

7. Ayangco L, Sheridan PJ. Development and treatment of retrograde peri-implantitis involving a site with a history of failed endodontic and apicoectomy procedures: a series of reports. Int J Oral Maxillofacial Implants 2001; 16:412-417.

8. Quirynen M, Vogels R, Alsaadi G, Naert I, Jacobs R, van Steenberghe D. Predisposing conditions for retrograde peri-implantitis, and treatment suggestions. Clin Oral Implants Res 2005; 16:599-608.

9. Rosenquist B, Grenthe B. Immediate placement of implants into extraction sockets: implant survival. Int $\mathbf{J}$ Oral Maxillofacial Implants 1996; 11:205-209

10. Evian CI, Emling R, Rosenberg ES, Retrospective analysis of implant survival and the influence of periodontal disease and immediate placement on long-term results. Int J Oral Maxillofacial Implants 2004; 19:393-398.
11. Deng F, Zhang H, Zhang H, Shao H, He Q, Zhang P. A comparison of clinical outcomes for implants placed in fresh extraction sockets versus healed sites in periodontally compromised patients: a 1-year follow-up report. Int J Oral Maxillofacial Implants 2010; 25:1036-1040.

12. De Bruyn H, Collaert B. Early loading of machinedsurface Branemark implants in completely edentulous mandibles: healed bone versus fresh extraction sites. Clin Implant Dent Relat Res 2002;4:136-42

13. Lekholm U. Immediate early loading of oral implants in compromised patients. Periodontol 2000. 2003;33:94-203.

14. Naves Mde M, Horbylon BZ, Gomes Cde F, Menezes HH, Bataglion C, Magalhaes D. Immediate implants placed into infected sockets: A case report with 3-year follow-up. Braz Dent J 2009;20:254-258.

15. Del Fabbro M, Boggian C, Taschieri S. Immediate implant placement into fresh extraction sites with chronic periapical pathologic features combined with plasma rich in growth factors: Preliminary results of single-cohort study. J Oral Maxillofac Surg 2009;67: 2476-2484.

16. Jofre J, Valenzuela D, Quintana P, Asenjo-Lobos C. Protocol for immediate implant replacement of infected teeth. Implant Dent 2012; 21:287-294.

17. Meltzer AM. Immediate implant placement and restoration in infected sites. Int J Periodontics Restorative Dent 2012; 32:e169-e173.

18. Gassling V, Purcz N, Braesen JH, Will M, Gierloff M, Behrens E, Acil Y, Wiltfang J. Comparison of two different absorbable membranes for the coverage of lateral osteotomy sites in maxillary sinus augmentation: A preliminary study. J Craniomaxillofac Surg 2013;41:76-82.

19. Dohan Ehrenfest DM, Rasmusson L, Albrektsson T. Classification of platelet concentrates: from pure plateletrich plasma (P-PRP) to leucocyte and platelet-rich fibrin (L-PRF).Trends Biotechnol. 2009; 27(3):158-67

20. Kawase T, Kamiya M, Kobayashi M, The heat-compression technique for the conversion of platelet-rich fibrin preparation to a barrier membrane with a reduced rate of biodegradation. J Biomed Mater Res B Appl Biomater. 2014:14. Epub ahead of print.

21. Sohn DS, Lecture titled with sinus and ridge augmentation with CGF and AFG, Symposium on CGF and AFG, Tokyo, June 6, 2010.

22. Villa R, Rangert B. Immediate and nearly function of implants placed in extraction sockets of maxillary infected teeth: a pilot study. J Prosthet Dent. 2007;97: S96-S108. 
23. Chang SW, Shin SY, Hong JR, Immediate implant placement into infected and noninfected extraction sockets: a pilot study. Oral Surg Oral Med Oral Pathol Oral Radiol Endod. 2009;107: 197-203.

24. Siegenthaler DW, Jung RE, Holderegger C, Replacement of teeth exhibiting periapical pathology by immediate implants: a prospective, controlled clinical trial. Clin Oral Implants Res. 2007;18: 727-737.

25. Lindeboom JA, Tjiook Y, Kroon FH. Immediate placement of implants in periapical infected sites: a prospective randomized study in 50 patients. Oral Surg Oral Med Oral Pathol Oral Radiol Endod. 2006; 101:705-710.

26. Werbitt MJ, Goldberg PV. The immediate implant: bone preservation and bone regeneration. Int $\mathrm{J}$ Periodontics
Restorative Dent. 1992; 12:206-217.

27. Mombelli A, Lang NP. Clinical parameters for the evaluation of dental implants. Periodontol 2000 1994; 4:81-86.

28. Anitua E. "The effects of PRGF on bone regeneration and on titanium implant osseointegration in goats: a histologic and hist1omorphometric study". Journal of Biomedical Materials Research Part A 91.1 (2009): 158-165

29. Rodella LF., "Growth factors, CD34 positive cells, and fibrin network analysis in concentrated growth factors fraction". Microscopy Research and Technique 74.8 (2011): 772-777.

30. Anitua E, Andia I, Ardanza B, Autologous platelets as a source for healing and tissue regeneration. Thromb Haemost 91:4, 2004 


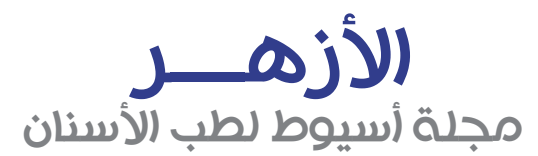

النشر الرسمي لكلية طب الأسنان

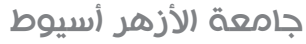

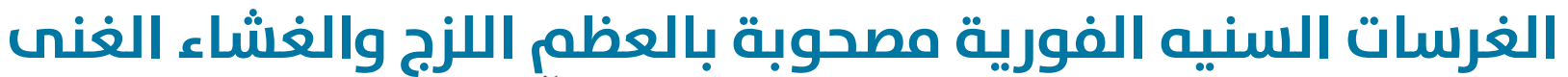 بالصفائح كبديل للأسنان المصحوبة بالية بآفات التحتح التحات القميه
}

\author{
محمد عزت عيد، * محمد عبد الاخر محمد، بهاء الدين عبدربه توفيق

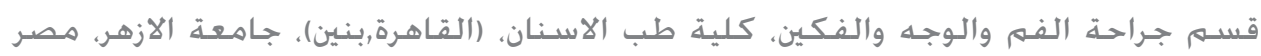

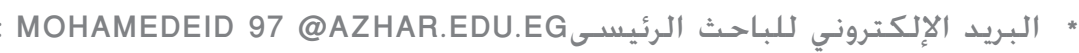

الملخص :

الهدف : تم تصميم هذه الدراسة لتقييم وضع الزرع الفوري مع العظم اللزج وغشاء الفيبرين الخصب للأسنان التي تظهر مرضًا حول قمة

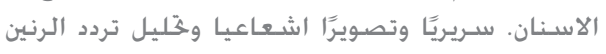

المواد والاسـاليب: تم عمل اشعة مقطعيه مخروطية قبل الجمراحة وتم أخذها لكل مريض لتحرة التحديد ارتفاع عظم السنخ وعرضه وعيوب العظام. تم قياس التغير في استقرار الغرسة وقراءات كثافة العظام باستخدام جهاز اوستيل و اشعهـ مقطعيه مخروطيه على الفور، وبعد 6 أشهر هن الشـفاء

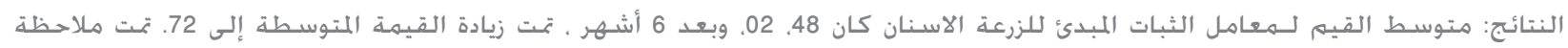

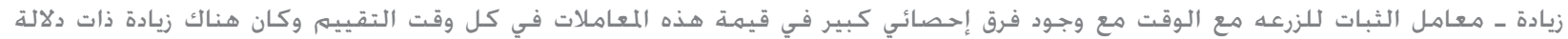
إحصائية في قراءات كثافة العظام بعد 6 أشهر.

الخلاصة: إن وضع الزرع الفوري مع العظام اللزجة وغشاء الفيبرين الخُصب للأسنان التي تظهر مرضًا حول قمة الاسنان هو تقنية ناجحة الكلمات المفتاحية: الزرع الفوري ، العظم اللزج ، وغشاء الفيبرين الخُصب للأسنان ، مرضًا حول قمة الاسنان ، اشعه مقطعيه مخروطيه 